\title{
Laying the Emphasis in Teaching the Geogeaphy of Asia
}

\section{R. H. Whitbeck}

To cite this article: R. H. Whitbeck (1911) Laying the Emphasis in Teaching the Geogeaphy of Asia, Journal of Geography, 10:2, 51-57, DOI: $10.1080 / 00221341108985640$

To link to this article: http://dx.doi.org/10.1080/00221341108985640

曲 Published online: 20 May 2008.

Submit your article to this journal $\square$

Џ Article views: 2

Q View related articles $\longleftarrow$ 
his leisure sitting on a hot stone in the white glare of the sun strumming a guitar. He must leap and run and slide, dance and shout in keeping with the wildness of the land and the tingling atmosphere. Perhaps the history, literature, music and character of man in Norway do not show the causal relations so strikingly as do the occupations and material prosperity of the people, but every one of these features and many others in greater or lesser degree bear the stamp of environment.

\section{LAYING THE FMPHASIS IN TEACHING THE GEOGRAPHY OF ASIA}

By R. H. WHITBECK, University of Wisconsin, Madison

DHYSICALI,Y Europe and Asia form a single continent. In every other particular they are as far apart as the East is from the West. Europe seeks intercourse with all nations; Asia, until compelled to change, opposed such intercourse. Europeans are colonizers, conquerors, traders, and travelers. Comparatively few Asiatics ever go outside of their own provinces. Asiatics do as their fathers have done for two or three thousand years. Rural life in Illinois has changed more in 25 years than it has in Syria since the days of Solomon or in Interior China since Confucius.

Strictly geographical influences-climate, coast line, topography, situation-have exerted a strong influence upon the development of European nations. Such influences are of necessity, operative in Asia, especially the fact that the only parts of Asia capable of supporting a large population are separated from Europe by one or two thousand miles of desert. The isolation of India, China and Japan has favored the establishment of fixed social and religious convictions which blocked progress. The Caste System, contempt for things foreign, exclusiveness, ancestor-worship, have left their impress on Asiatic peoples. But Asia is awaking. The next hundred years are likely to be fraught with the most significant changes that any continent has experienced in that length of time.

We study Europe as a laboratory where men are busy, increasing knowledge, increasing productivity, improving processes, extending influence. Europe is a continent of factories, railroads, schools, armies and fleets. Asia is a museum, the repository of ancient customs, depressing religions, and antiquated methods.

In studying the geography of Asia, I believe the aim is not so much to memorize facts as to get pictures; to gain realistic impressions of the people, not uncivilized, but differently civilized. The foreign commerce of Asiatic countries is small, and calls for no particular emphasis. The leading five commercial nations of Asia all put together have less foreign 
trade than the Netherlands alone. Our trade with all Asia is less than our trade with Canada, and Canada has 8 million people while Asia has eight hundred million.

\section{ASIA AS A WHOLE}

(1) Its Great Size.-Asia contains one-third of the land surface of the globe. Seventy-five countries as large as Germany could be carved from its area. Asiatic Russia in twice the size of all Europe. The Arabian peninsula, for example, is half as large as Europe.

(2) Its Striking Contrasts of Topography.-Asia has mountains nearly six miles high, whose peaks penetrate where the atmosphere is so thin that man cannot keep alive in it. Their valley bottoms are as far above the sea-level as are the tops of the Alps. There are intermontane valleys into which the Pyrenees could be dropped and lost.

Asia has the greatest extent of plains in the world. One quarter of the continent rises less above the sea-level than some of the offices in the Singer Building in New York. It has also the loftiest and most extensive plateaus. One-twelfth of the land rises above 10,000 feet; on the other hand almost as much more is actually below sea-level. All of the Great Lakes of North America could be poured into the Caspian depression and yet not make a Caspian Sea.

Toward the Arctic is a vast zone of tundra from which the frost never escapes, the treeless abode of a few half-frozen people. Great areas are arid steppes, "no man's land", over which wandering tribes drive their flocks in search of scanty pasture. The deserts of Asia exceed in area the entire United States, and nearly a third of the continent is so low and flat that it has no drainage to the sea.

(3) Its Great Range of Climate and Products. - Its extension gives it every variety of heat and cold. The coldest known place in the world is in northeastern Siberia. One of the hottest is in Arabia. The southern slopes of the Himalayas have by far the heaviest rainfall of any part of the world. Six hundred inches of rain sometimes fall in a single year, and four hundred inches is the ordinary fall. As much falls in an occasional single down-pour as Chicago gets in a year. Yet, some other parts of the continent go two or three years almost without a drop of rain. The result of all this is an enormous range of products. Asia yields substantially every product known to the commerce of the world. In Asia, Nature has concentrated her superlatives: hottest and coldest, highest and. lowest, wettest and driest, most fertile and most barren, densest populations and most sparse.

(4) Its Great Areas of Unproductive Land.-Despite its size, the cultivated portions of Asia are relatively small, and must, under present climatic conditions, remain so. One-half of Siberia, an area nearly as large as Europe, lies north of the sixtieth parallel, and, with a continental 
climate, is too cold for agriculture. Of the remainder, one-half is too dry for farm crops. More than half of the Chinese Empire is desert or nearly desert. Only a minor part of south-western Asia has sufficient rainfall for crops, either with or without irrigation. Probably Europe, small as it is, has nearly as much land actually under cultivation as has Asia, five times as large.

(5) Its Vast Population, Very Unevenly Distributed.-The average density of population in Asia is only half that of Europe, yet, a single division of the Chinese Fmpire, China proper, has nearly as many people as the whole of Europe. Half of the people of the globe live in Asia, but seven-ninths of these are huddled in the southeastern quarter of the continent and the neighboring islands. The remaining three-quarters of Asia would give each family that dwells in it a square mile of land, and in much of it each person might have a square mile. On the other hand, in the fertile flood plains of the southeastern rivers and in Japan, the population is very dense. The vast majority of people in China, Japan, and India, cultivate little pieces of land, and they have little money with which to buy anything; 70 per cent of the farmers of Japan cultivate less than $2^{1 / 2}$ acres each. They must compel their patches of land to feed them. If a crop fails there is suffering. Belgium, Saxony and England are as densely populated as China or India, but great numbers of their people earn money by manufacturing, mining, and transportation, and with their earnings they may buy imported food. Millions, in interior China, never tasted food that did not grow on Chinese soil, while more than half of the Londoner's every meal comes from over the sea.

(6) Government, Religion, Civilization, Races.-Asia belongs to the past, the far remote past, when despotic governments and walled cities were the rule. It has been a cradle of civilization and from it, civilizing influences moved westward, usually carried by the migrating peoples who chose to leave or were forced to leave their Asiatic abodes. For three thousand years the ever-evolving, ever-progressing civilization, languages, and one of the religions, of Asia have slowly pushed westward around the world, and are now returning to the continent that gave them birth. Japan, the first of the oriental nations to accept western ideas, has applied them with a thoroughness and celerity that have commanded the admiration of the world. We must not under-rate the capacities, or the possibilities of the Asiatics. They are neither stupid nor lazy. Their better classes are intellectual, their artisans are skillful, their architects have produced some of the world's most beautiful buildings. The Taj Mahal of India, the silks and porcelains of China, the rugs of Persia, the inlaid work of Japan, tell of the taste and skill of their artists and workmen. The great wall of China is a marvel to modern engineers. Damascus made the best steel, and Arabia yet breeds the finest horses in the world. All this 
is true, and it is also true that millions upon millions of Asiatics are ignorant, hungry, and hopeless.

Asia, probably Tibet, was the original home of the great Mongolian race, which now forms a third of the world's population. Most of the Mongolian race live in the southeastern third of Asia and the nearby islands. The white race is more numerous and more widely dispersed over the world. In India, in southwestern and western Asia and in parts of Siberia the Caucasian race predominates. Asia not only was the cradle of the world's religions but it is the present home of practically all the follers of Buddha, Brahma and Confucius and of the major part of the Mohammedans. While Christianity originated in Asia, it has never been an Asiatic religion.

\section{THE COUNTRIES OF ASIA}

Siberia will call for little attention beyond what it receives in connection with European Russia, and with Asia as a whole. Korea will naturally be included with Japan. India, China, and Japan will properly claim most of the time which is allotted to the teaching of the countries of Asia.

It is my opinion that the method of treatment employed when teaching Asiatic countries should differ considerably from that used for North America and Europe. Less time is allotted to Asia. The industries are few and simple; life is far more primitive. Comparatively few cities need be even mentioned. Foreign trade is relatively small in value and variety. Seemingly the thing to do is to give as vivid pictures as possible of the way these people live; their homes, their towns, their characteristic ways of doing; the few lines of industry in which they are particularly skillful, a little about their religions, education, methods of travel and transportation, the changing attitude toward other nations and toward western ideas. I would treat physiography briefly, touching only on those points which have as marked influence upon climate and upon human conditions.

THE EMPIRE OF INDIA

Three points in its physiography deserve attention:

(1) The plateau nature of the peninsula, giving a regular coast with almost no natural harbors.

(2) The great wall of the Himalayas, precipitating in enormous quantities the moisture of the southwest monsoons, and supplying water and silt for the Ganges, Indus and Brahmaputra. This mountain wall protects India from the chilling influence of north winds much as the Alps protect Italy.

India is made up of "many distinct and independent communities owning no brotherhood of religion, language, race, or social intercourse." 
There are innumerable sects but the caste system is general. A great number of languages and dialects are spoken. Two-fifths of the territory is not directly administered by the British but is under native chiefs. A handful of British rule India. There are 3000 natives to every Briton. Ninety-five per cent of all those holding official positions are native Indians.

Most of the people till little pieces of land, living in small villages. Not over five per cent of the people live in cities. The people seldom move from one place to another, but are peculiarly attached to the place of their birth. The factory system has begun in a few cities. In the valley provinces there are over 500 people to the square mile. In some provinces there are as low as 12 to 30 to the square mile.

Calcutta, Bombay, Madras, Benares and perhaps Delhi deserve brief individual treatment.

\section{THE CHINESE EMPIRE}

(1) The Large Area.-It is larger than all Europe, a third !:rrger than the United States, and twenty times larger than France.

(2) Its mountainous surface.-Some of the ranges are of greal extent. The country is a series of ranges and valleys, withont extensive flains except flood plains. Tibet is a mighty flateau, littls known.

(3) The great deserts and arid lands.-Nearly two-thirds of the empire is too dry for crops and much of it is desert. The plateaus, mountains and deserts which intervene between China proper and the rest of Asia have been effective barriers, hindering communication, shutting China away from the world, promoting exclusiveness, if not actually causing her to keep apart.

(4) The rivers and flood plains.-The latter are very fertile, highly cultivated and densely populated. The Yangtze is the great highway of the Empire. Ocean steamers ascend the river 700 miles to Hankow and smaller steamers ascend 1100 miles. The floods of the Hoang-Ho are appalling, sometimes killing as many as a million people. Its lower course has changed eleven times in 2500 years. Much of the internal commerce of the empire is carried on in river boats of every description.

(5) The rich but undeveloped mineral resources.-China is said to be among the richest of lands in coal, one of the chief factors in the building of an industrial nation. Because of poor transportation facilities and opposition to modern inventions, the mines are largely undeveloped.

(6) The productions might be practically like those of the United States, but the Chinese have for centuries been producers of tea, silk and rice. These are their great staples. Rice for food; silk for their own hand looms, and for export; tea for the world and particularly for the overland trade both north and west.

(7) The enormous population.-If the people of the Chinese Empire were evenly distributed, the population would not be especially dense; less 
so than in Germany. However, some seven-eighths of the $400,000,000$ people are huddled into China proper. In the rest of the empire, the people are thinly scattered and largely pastoral or even nomadic. In the southeastern quarter, there are more people to the square mile than in any other large area in the world. They live by thousands in house boats on the rivers. Every available patch of land is cultivated. Soil is often carried in baskets and spread over rocky places. The steep slopes are terraced sometimes as high as 8000 feet up the mountains. The marshy lands are reclaimed for rice fields. Tens of thousands live by fishing. Farming is the most honored occupation and the vast majority of the people are small farmers.

(8) The Chinese people.-The Mongolians were originally immigrants into China. They came thousands of years ago from Western Asia and have gradually absorbed or exterminated nearly all of the former peoples, and have slowly pushed their boundaries outward to their present limits. The present rulers are of Manchu origin, not Chinese. As a race, the Chinese are exceedingly industrious, thrifty, patient, and peaceable, able to do the hardest kinds of work on a meager diet, shrewd tradesmen, devoted to their ancestors and unwilling to do anything not practiced by them.

\section{JAPAN}

Five points call for emphasis:

(1) The remarkable transformation of the nation in the last half century.

(2) The traits of a people who are capable of such progress.

(3) The physical limitations of the empire, the rapidly growing population, the national ambition, the inevitable expansion of territory and possible conflicts.

(4) The hoped-for industrial and commercial expansion along the lines already followed by Great Britain.

(5) The present and future relations between the United States and Japan.

Two distinct lines of interest will be developed in connection with Japan. Young pupils will find the chief interest in the peculiar homes of bamboo and matting, the scanty furniture and few utensils, the odd dress of the women and children, the travel by jinrikisha or chair, the pagodas and strange religion, the customs and manners and other points pertaining to the daily life of the people. Older pupils, and particularly boys, will have heard or read about the late Russo-Japanese war, and will read in the press of the imaginary but much discussed danger of war between Japan and ourselves. These pupils should know the leading facts about the rise of the New Japan to the rank of a world power. They should 
know that the Japanese are a people of proved ability, dauntless courage in war, unswerving loyalty to country and emperor, boundless ambition, restless energy, and yet compelled to live in a little island empire, the size of California, only an eighth of which is arable, with valuable but limited mineral resources.

The pupil should see that such a land can not long contain such a people: that the war with Russia was unavoidable if Japan preserved for her increasing population an outlet into Korea and perhaps Manchuria; that the absorption of Korea by Japan was practically inevitable; that further territorial expansion seems certain and hence the suspicion by some people that Japan desires the Philippines; that Japan has coal and some metals, that her people are mechanically inclined, and that she aspires to become the manufacturer for the East and thus, as in the case of England; be able to exchange the products of her mills for the food stuffs and raw materials which her small area is incapable of supplying.

\section{CURRENT EVENTS AND GEOGRAPHY}

By MARY E. KELTON, Ely School, Greenwich, Conn.

$\mathrm{T}$ $\mathrm{HE}$ study of the earth in its relation to man has established its right in the school curriculum. The question that now confronts us is how to make this subject of geography most vital.

The press is universally making geography a leading topic in its pages and the editorial columns frequently furnish valuable notes for a geographical text. One leading New York paper has gained popularity through such sketches in its Sunday issue. When the great financial problems of the world are brought face to face with the geographical causes that effect them, it must be in the pages of the daily press that the geographical text has its most vital significance. This power of the press in the affairs of men places the current news item as an important factor in the geography instruction of the elementary school.

The value of place location proves itself when the boy and girl begin to read the daily paper, and its chief significance is never apparent before. Memorizing capitals, a questionable exercise in the eyes of the psychologist, then becomes easy. Guthrie has a meaning to the boy who is interested in the current events of Oklahoma, since the news items of its affairs of state are dated from its capital. The unpronounceable Cetinje holds its place in the mind when Montenegro becomes an interesting topic in the pages of the daily paper.

A systematic treatment of current events may produce a combination of exercises relating to civil government, history and geography as well as 